\title{
Терехова О.П.
}

\section{Формирование гражданских качеств молодежи на примере исторического наследия чувашского народа}

ФГБОУ ВО «Чувашский государственный университет имени И.Н. Ульянова» (Россия, Чебоксары)

doi: $10.18411 /$ sr-10-02-2020-33

idsp: sciencerussia-10-02-2020-33

\section{Аннотация}

В данной статье рассматривается проблема использования национальнорегионального компонента как одна из форм формирования гражданских качеств, активизации познавательных интересов, общественной, нравственно-экологической позиции студентов в учебном процессе. Объектом исследования является роман народного писателя Чувашской Республики М. Юхмы «Термен». В центре романа жизнедеятельность, нужды и тревоги чувашского народа во второй половине XIX начале XX веков. Автор рассказывает о появлении чувашской письменности, как благодаря заботам просветителя И.Я. Яковлева чувашский народ, погибающий из-за темноты, тяжелого гнета, за период жизни одного поколения вошел в число культурных народов Европы. В романе показаны взаимоотношения между русским и чувашским народами, помощь прогрессивной русской интеллигенции в просвещении чувашского народа, связи чувашского народа с представителями разных регионов России.

Ключевые слова: национально-региональный компонент, просвещение, национальная школа, развитие культуры, подготовка учителей, взаимоотношения между русским и чувашским народами, национальные традиции, обучение сельскому хозяйству, дружба народов.

В Чувашии, как и у многих других народов, важным всегда считается воспитание подрастающего поколения в духе гражданственности и патриотизма. На первом месте является воспитание нравственности, любви к родителям, ближним, природе, труду, Отечеству. Исследователи считают, что национальные традиции имеют прямое отношение к гражданскому воспитанию подрастающего поколения, они формируют и укрепляют национальное самосознание, без чего невозможны чувство собственного достоинства и патриотизм, осознание смысла жизни и гражданского долга.

Профессор Т.Н. Петрова подчеркивает, что «память - величайшее свойство духовно-нравственного, даже материального бытия. Каждое обращение к прошлому обогащает будущее. Оно расширяет культуру, усиливает эмоциональное восприятие окружающей жизни, дает более четкое восприятие своей судьбы» [4, с. 38]. В Чувашской Республике в учебно-воспитательной работе общеобразовательной и высшей школы педагоги обращаются к этнокультурным традициям и обычаям, описанным в исторических и художественных произведениях., потому что они позволяют показать многообразные связи чувашского народа с представителями разных регионов России, формируют представление о взаимных связях между различными национальными культурами, воспитывают любовь к своему родному краю.

Министерством образования Чувашской Республики принят приказ «О внедрении национально-регионального компонента в учебно-воспитательный процесс», реализация этого приказа касается всех предметов, всех ступеней обучения.

В Чувашском государственном университете им. И.Н. Ульянова на строительном факультете, как и на других факультетах, изучается предмет «История и 
культура Чувашии». На этих занятиях одним из средств воспитания у студентов любви к родному краю, народу являются произведения, описывающие историю, пейзаж родного края, жизнь знаменательных людей, их труд: вклад в историю развития культуры и просвещение чувашского народа.

Преподаватели по многим темам программы на занятия привлекают роман «Термен» народного писателя Чувашии Михаила Юхмы. В нем ярко, самобытно и с большой художественной силой показана жизнь чувашского народа за последние несколько столетий. Ведя многие годы неравную трагическую борьбу за национальную свободу, самобытность и независимость чувашский народ как бы потерял свои внутренние духовные силы, он стал уходить в небытие: шло повальное обрусение, уход в татары, переселение в Турцию. Эти факты вызывают у студентов сильное переживание. Данным событиям в романе посвящена целая глава. Вот один из примеров: «После окончания Симбирской чувашской школы Димитрий Архипов решил посетить деревню Шемалаково Буинского уезда. По пути встретились крестьяне, на семи подводах везущие бревно в Шемалаково, чувашские крестьяне решили построить мечеть, нашли человека, который будет муллой. Архипов крестьянам говорит: «Как же вы стали татарами? Не помните свой род, перестали почитать своих родителей, могилы родственников?». Крестьяне ответили: «Будучи чувашами, мы жили в нищете. Вон в соседней деревне Канпек жители, став татарами, стали жить зажиточно. Татары им раздали пустующие земли уехавших в Турцию крестьян, заплатили налог. Будучи чувашами, мы живем в нищете. Мы решили принять ислам, стать татарами» [10, с. 152-157]

В романе мы видим описание погибших чувашских сел: жители уходят в Турцию. Некоторые родственники даже получали письма из Турции. Автор романа в архивах знакомился с такими письмами, приводит их содержание.

Д.Архипов с согласия Ивана Яковлевича съездил в Турцию, встречался там со многими чувашами, приехавшими из России, живущими здесь целыми семьями [10, c. 162-163, 166-169].

В романе «Термен» писатель рассказывает о появлении чувашской письменности, интеллигенции, повествует о том, как благодаря заботам, стараниям просветителя И.Я. Яковлева чувашский народ, погибающий из-за темноты, тяжелого гнета и безысходности, за период жизни одного поколения вошел в число культурных народов Европы.

Патриарх чувашской культуры И.Я. Яковлев создал новый алфавит, примирил древнюю чувашскую религию с агрессивно наступающим православием, он также помог своим соплеменникам поверить России. Писатель подчеркивает: историю народа рассказывают не только исторические хроники, документы, летописи; лучше всего историю народа раскрывают обычаи, традиции, мифология, фольклор, все этническое богатство нации. Только собирая воедино все это, можно рассказать всю правду исторического пути народа.

Профессор В.Д. Димитриев называет «Термен» «документальным историческим романом». Он подчеркивает, что «В 1990 году М.Юхма опубликовал роман «Термен», посвященный художественному отображению дум и чаяний, великих дел просветителя чувашского народа Ивана Яковлевича Яковлева» [2, с. 84].

Как описано в романе, гимназист И.Я. Яковлев в 1868 году открыл первую чувашскую частную школу, которую поддержал Илья Николаевич Ульянов, назначенный в 1869 году инспектором народных училищ Симбирской губернии.

В 1870 году И.Я. Яковлев поступил в Казанский университет. В первый же месяц учебы познакомился с профессором Казанского университета Николаем Ивановичем Ильминским, разработавшим систему просвещения инородцев (нерусских народов) Востока России. Н.И. Ильминский стал учителем и руководителем И.Я. 
Яковлева и при создании чувашской письменности, и при разработках им системы просвещения народа.

В 1875 году, после окончания университета, Яковлев был назначен инспектором чувашских школ Казанского учебного округа и директором Симбирской чувашской школы, ставшей вскоре учительской школой с мужским и женским отделениями.

В романе «Термен» писатель показывает, как великий просветитель успешно осуществил свою программу по национальному подъему чувашского народа, повышению его культуры до уровня русской культуры, созданию чувашской письменности, внедрению в начальных классах училищ обучения на чувашском языке, с широким использованием и русского языка, изданию книг на чувашском языке, подготовке учителей для чувашских школ, открытию чувашских школ, зарождению чувашской художественной литературы и профессионального искусства, его равноправие с русским и другими народами России. В романе показано, «как И.Я. Яковлев многое сделал по изданию на чувашском языке и распространению в народе произведений классиков русской литературы: А.С. Пушкина, М.Ю. Лермонтова, И.А. Крылова, Л.Н. Толстого и др. [6, с.6]

Открытой и руководимой И.Я. Яковлевым Симбирской чувашской учительской школой было подготовлено более тысячи учителей для чувашских школ. В школе юноши обучались также сельскому хозяйству и ремеслам, девушки - домоводству и рукоделиям.

На протяжении всего романа «Термен» проходит главный герой - Семендей. На его пути параллельно выступает будущий просветитель чувашского народа И.Я Яковлев. Он показан с детства и до становления его руководителем Симбирской чувашской школы. Основные события романа связаны с жизнью и судьбой главного героя - Семендея. Например, обряд «кража земли». Доведенный до отчаяния, чтобы спасти себя от неурожая, сельчане живьём должны были положить в могилу молодого парня, единственного сына в семье. Как объясняет академик Н.И. Ашмарин, «этот обряд «кража земли» проводился в случаях, если поле начинало давать плохой урожай. Тогда сельчане скрытно отправлялись в чужое село и привозили землю-невесту, а в качестве жениха выступал юноша - единственный сын в чьей-либо семье. И согласно обычаю, этот парень по настоящему уже жениться не мог»[1, с. 92]. Такая судьба выпала Семендею, которого спас от смерти молодой И.Я. Яковлев.

Трудную жизнь, тяжёлую жизнь прожил Семендей. Погибла жена, которую он любил безмерно. Потерял единственного сына. Вдруг в мальчике, который играет на скрипке вековой гимн чувашских земледельцев, узнает своего сына, которого тоже спас И.Я. Яковлев, а сейчас обучает в Симбирской чувашской школе. Это тоже символично.

Все творчество Михаила Юхмы очень тесно и органически связано с жизнью и культурой чувашского народа, в его произведении ярко проявились наиболее характерные обычаи, традиции, обряды чувашей. Изучение истории является тем средством, которое помогает творчески применять жизненный и духовный опыт прошлых поколений в настоящем и будущем. В романе мы видим многих замечательных дочерей и сыновей чувашского народа: известного математика Н.М. Охотникова, композиторов С.М. Максимова, Ф.П. Павлова, классика чувашской литературы К.В. Иванова, прославленную певицу К. Эсливанову, основателя первой чувашской газеты Н.В.Никольского, основоположника чувашского языкознания Н.И. Ашмарина и др. Художественный образ каждого из них в романе неповторим, для каждого у автора нашлись свои краски, своё художественное видение.

В романе раскрывается деятельность С.В. Чичериной, А.Н. Бобровникова, Н.И. Ильминского, А.В. Рекеева, В.К. Магницкого в просвещении чувашского народа. Подробно описана дружба инспектора народных училищ Ильи Николаевича Ульянова, членов его семьи и И.Я. Яковлева. «Илья Николаевич не только поощрял и 
поддерживал инициативу И.Я Яковлева по созданию в Симбирске чувашской школы, но и непосредственно участвовал в этом». [7, с.15]

Исследователь В.Н.Пушкин подчеркивает, что «Чувашский народ всегда был верным союзником русского народа, при этом всегда доброжелательно и с уважением относится ко всем другим народам, не ставя себя в этническое противостояние с ними вот идеи, которые красной нитью проходят через многие произведения Юхмы» [5, с. 114]. При этом чуваши стремились максимально сохранить преданность своим национальным традициям, обычаям, вере, в процессе чего значительно взаимообогатили культуру и свою, и своих соседей.

В романе «Термен» подчеркивается, что И.Я. Яковлев был беспредельно предан своему народу, вывести его из нищеты и бесправия, по его мнению, можно было путем образования широких слоев населения, включая женщин. Развитие национальной культуры нерусских народов России он не мыслил без влияния передовой русской культуры.

Использование родного языка, привитие любви к нему Яковлев считал средством развития культуры. «Без родного языка нет национальной школы, родной язык - это наилучшее средство познания истории народа, его духа, воспитания любви и уважения к родному народу, к родной земле. Человек, не уважающий свой родной язык, не уважает свой родной народ, не позволяет формировать у подрастающего поколения национального самосознания и достоинства» [8, с. 26].

И.Я. Яковлев говорил, что культура каждого народа, как стол, должна основаться на четырех ногах: художественная литература, живопись, музыка, сценическое искусство. Учитывая это, развитие культуры чувашского народа М.Юхма описывает через развитие чувашской художественной литературы, живопись, музыкальное искусство, сценическое искусство. Поэтому в романе описаны жизнь и деятельность известных представителей литературы, музыки, живописи, сценического искусства.

Действия в романе «Термен» кончаются описанием событий 1913 года. Ивану Яковлевичу скоро исполнится 65 лет. Он уже 45 лет заведует Симбирской чувашской школой. Школа, открытая патриархом, чувашский народ ведет к светлой жизни. Симбирская чувашская учительская школа для чувашского народа стала и своеобразным университетом, и книжным издательством, и научно-исследовательским институтом, и художественной галереей, музеем, - одним словом, культурнопросветительским центром.

В романе это показано очень убедительно. Исследователи подчеркивают, что автор при составлении этой книги тщательно изучал, анализировал сотни исторических документов, письма, воспоминания, выбрал нужные теме произведения, обобщил, художественно обработал. Роман представляет собой, по словам К.Петрова, «как бы большой дворец, исторические события, документы составляют его отдельные бревна, кирпичи» [3, с. 5].

Таким образом, использование национально-регионального компонента в учебно-воспитательном процессе способствует формированию гражданских качеств, нравственному, патриотическому и интернациональному воспитанию молодежи, формированию у студентов познавательного интереса к истории республики, народа, культуры родного края.

$$
* * *
$$

1. Ашмарин Н.И. Словарь чувашского языка. Чебоксары,. 1899-1937.

2. Димитриев В.Д. Исторический роман / Певец народа. Чебоксары, 2012. 126 с.

3. Петров К. Большое исследование.- Чебоксары, Чуваш. кн. изд-во, 1990. с. 5-8.

4. Петрова Т.Н. Чувашская педагогика как феномен мировой цивилизации. М.: Прометей, 2000. 91 с.

5. Пушкин В.Н. Истинно народный писатель // Крылатый сын Чувашии. Чебоксары, 2006.132 с. 
6. Терехова О.П. Экологическое воспитание в сельской школе: учебное пособие - Чебоксары: Изд-во Чуваш. ун-та, 2009. $256 \mathrm{c.}$

7. Терехова О.П. Система экологического воспитания и обучения в учебных заведениях Чувашии в ее историческом развитии. Чебоксары: Изд-во Чуваш ун-та, 2016. 362 с.

8. Терехова О.П. Творческая поддержка И.Я. Яковлева исследователя чувашского языка Н.И. Ашмарина // Медународная научн-практич.конференция. Чебоксары, 2019. с. 207 - 211.

9. Терехова О.П. Роль национально-регионального компонента в патриотическом воспитании учащихся // Развитие социально-устойчивой инновационной среды непрерывного педагогического образования. .Абакан, 2017. с. 257 - 264.

10. Юхма М.Н. Термен: роман. Чебоксары: Чуваш. кн. изд-во, 1990.464 с

\section{Юнкин В.В. \\ Роль воспитателя в создании и развитии кадетского коллектива}

ФГКОУ «Ставропольское президентское кадетское училище» (Россия, Ставрополь)

doi: $10.18411 / \mathrm{sr}-10-02-2020-34$

idsp: sciencerussia-10-02-2020-34

Воспитание - это творческий, непрерывный, целенаправленный системный процесс взаимодействия воспитателей и воспитанников по созданию оптимальных условий для развития индивидуальных особенностей, самоактуализации личности. Важным звеном модернизации воспитательной практики является обновление деятельности воспитателя, его позиция. Именно он - ключевая фигура во взаимодействии с детьми, родителями, учителями - предметниками, психологом, социальным педагогом. Тенденции развития современного общества требуют инновационного подхода к образовательной подготовке кадет. Перед СПКУ ставится новая задача: подготовить воспитанника к новым, быстроменяющимся условиям, что требует:

- во-первых, создание такой обучающей среды, которая мотивирует учащихся самостоятельно искать, добывать, обрабатывать информацию, обмениваться ею, быстро ориентироваться в информационном пространстве;

- во-вторых, создание условий, содействующих наиболее полному развитию способностей кадет.

Таким образом, проблема активного, творческого поиска, получения и восприятия знаний как никогда остро стоит перед сегодняшней школой. Учебный процесс должен помочь воспитанникам раскрыть значение получаемых в училище знаний и показать их практическое применение в жизни. Необходимость решения этих проблем порождает потребность во введении новых педагогических технологий в учебный процесс. В основе этой деятельности лежит приобретение личностного и профессионального опыта в процессе обучения нестандартными методами; развитие познавательных навыков учащихся, выработка у учащихся стремление и умения самостоятельно участвовать в творческом исследовательском процессе. Мы все родом из детства. Вспоминая детство, каждый взрослый человек часто воспроизводит события, связанные с его жизнью в школьные годы. Добрая память остается о том педагоге, с которым были радостные минуты общения, который помогал в решении проблем, в выборе жизненного пути, был интересной личностью. Чаще всего - это воспитатель. Он действительно ближе всех стоит к кадету в педагогическом коллективе училища. Проблемы здоровья, поведения, учебы, взаимоотношений с одноклассниками, учителями-предметниками, организация досуга воспитанников и многое другое являются сферами заботы воспитателя. Поэтому можно сказать, что он - одна из ключевых фигур в процессе развития и саморазвития кадета, становления его мировоззрения. С чего начинается работа классного наставника? Каждый педагог 